\title{
Willingness of Parents to Pay for Space Maintainer Therapy for their Children
}

\author{
Sarah Mubaraki ${ }^{1 *}$, Shatha Abubotain², Sara AlDhahri ${ }^{2}$, Rawan AlGhamdi ${ }^{2}$, Ruba AlOtaibi ${ }^{2}$ and Sharat Pani ${ }^{1}$ \\ ${ }^{1}$ Department of Preventive Dental Sciences, Riyadh Colleges of Dentistry and Pharmacy, Saudi Arabia \\ ${ }^{2}$ Department of Dental intern, Riyadh Colleges of Dentistry and Pharmacy, Saudi Arabia
}

Submission: February 13, 2017; Published: July 28, 2017

*Corresponding author: Sarah Mubaraki, Department of Preventive Dental Sciences, Pedodontic Division, Riyadh Colleges of Dentistry and Pharmacy, Saudi Arabia, Email: sarah.mubaraki@riyadh.edu.sa

\begin{abstract}
Background and Objective: Space maintainers are the most commonly used tools of interceptive orthodontics. Since their benefit is not immediately visible to the parents there is the possibility that they would not be willing to pay for interceptive care.

Methodology: 155 families of children who had lost a primary tooth prematurely participated in the study. A short description of the potential benefits of space-maintainers, parents were asked if they are willing to pay the median cost, Parents who are unwilling to pay the median price will have the price reduced by 50 SR until they reached a price they would be willing to pay and for parents who are willing to pay the median price had the price progressively increased by $50 \mathrm{SR}$ until they were no longer willing to pay.
\end{abstract}

Results and conclusion: The results of the study showed that Parents education, nationality and relationship to the patient was not statistically significant, however Family monthly income and WTP value for the space maintainer were associated.

Keywords: Space maintainers; Willing to pay; Interceptive orthodontics; Dental economics; Bidding

\section{Introduction}

Interceptive orthodonticsis an important method of preventing extensive malocclusion and often-costly orthodontic care. Space maintainers are the most commonly used tools of interceptive orthodontics. Given that the benefits of space maintenance are not immediately visible to the parents there is the possibility that they would not be willing to pay for interceptive care.

In the past few decades there has been a great interest in the field of dental economics with authors seeking to estimate the cost effectiveness of several treatments [1-3]. The concept that delaying dental care results in increased costs is only now being scientifically evaluated [4].

Assessing a patient's willingness to pay (WTP) is one of the most accepted methods to evaluate the acceptability of new treatment modality for the clinician. It has been used to successfully measure patient's perception in not only in dentistry $[1,4,5]$, also in medical field such as orthopedics [6] cardiology and health care service preferences (Fu et al 2004).

Bidding is the oldest and most accepted tool to assess WTP of a patient and provides both clinicians and third party payment providers with a realistic estimate of how much a patient can spend on a treatment modality (McName et al 2004).
The aim of this study was to evaluate the willingness of parents to pay for space maintainers in Riyadh City in Saudi Arabia.

\section{Methodology}

The sample comprised of 155 Parents of children aged between 5 and 9 years who have undergone extraction of at least one primary tooth presenting to the dental clinics of the Riyadh Colleges of Dentistry and Pharmacy.

\section{Bidding process}

Four investigators were trained for the bidding process for data collection and calibrated against the lead investigator (SCP).

\section{Conducting the bidding}

Parents who consent to participate in the study was given a form in Arabic asking them to fill in their demographic data, the bidding process administered in a two-stage process.

Stage 1: Description of the potential benefits of spacemaintainers and then the parents were asked if they are willing to pay the median cost of the space maintainer needed for their child in Riyadh city, which is 600SR.

Stage 2: The parents were allowed to bid for the price they would be willing to pay. Parents who are unwilling to pay the 
median price will have the price reduced by 50 SR until they reach a price they would be willing to pay or the amount reaches 0 SR. Parents who are willing to pay the median price had the price progressively increased by 50 SR and asked if they would still be willing to pay for the space maintainer, the price will be progressively increased until the parents is longer willing to pay or until they reach the maximum price charged for space maintainer in Riyadh city, whichis1800 SR.

Statistical analyses: All statistical analyses was done using SPSS ver 22 data processing software (IBM Corp, Armonk NY,
USA). Apart from descriptive statistics, linear regression models will be developed to determine the factors that influence the willingness to pay for space maintainers.

\section{Results}

A total of 155 families were able to participate in the study, the sample compromised of 44 Fathers, 97 mothers and 14 who is related to the child in other way (Table 1).

Table 1: Relationship to the child.

\begin{tabular}{|c|c|c|c|c|}
\hline & & \multicolumn{3}{|c|}{ Nationality } \\
\hline & & Saudi & Non-Saudi & Not Mentioned \\
\hline & & Count & Count & Count \\
\hline \multirow{3}{*}{ Relationship to Child } & Father & 36 & 8 & 0 \\
\hline & Mother & 66 & 26 & 5 \\
\hline & Other & 13 & 1 & 0 \\
\hline
\end{tabular}

\section{Factors affecting WTP}

Majority of parents shows their willingness to pay for the space maintainer (Table 2).

Table 2: Parent relation and willingness to pay.

\begin{tabular}{|c|c|c|c|c|}
\hline \multicolumn{2}{|c|}{} & \multicolumn{3}{|c|}{ Relationship to child } \\
\cline { 3 - 5 } & Father & Mother & Other \\
\cline { 3 - 5 } & Count & Count & 10 \\
\hline \multirow{2}{*}{$\begin{array}{c}\text { Willingness } \\
\text { to Pay }\end{array}$} & Yes & 21 & 50 & 4 \\
\cline { 2 - 5 } & No & 23 & 47 & 4 \\
\hline
\end{tabular}

Table 3: Factors affecting the WTP.

\begin{tabular}{|c|c|c|c|c|c|c|}
\hline \multicolumn{7}{|c|}{ Coefficientsa } \\
\hline & \multirow{2}{*}{ Model } & \multicolumn{2}{|c|}{ Unstandardized Coefficients } & \multirow{2}{*}{$\begin{array}{c}\begin{array}{c}\text { Standardized } \\
\text { Coefficients }\end{array} \\
\text { Beta }\end{array}$} & \multirow{2}{*}{$\mathbf{t}$} & \multirow{2}{*}{ Sig. } \\
\hline & & B & Std. Error & & & \\
\hline \multirow{6}{*}{1} & Education of Father & 2.219 & 2.446 & 0.069 & & \\
\hline & Education of Mother & -4.404 & 2.423 & -0.136 & -1.817 & 0.071 \\
\hline & Income` & 160.565 & 23.055 & 0.501 & 6.964 & 0 \\
\hline & Nationality & 0.42 & 1.768 & 0.017 & 0.238 & 0.813 \\
\hline & Relationship to Patient & 83.189 & 53.699 & 0.112 & 1.549 & 0.123 \\
\hline & Relationship to Patient & 83.189 & 53.699 & 0.112 & 1.549 & 0.123 \\
\hline
\end{tabular}


Factors that could affect the WTP were calculated by using a linear regression model to determine the significant difference (Table 3). Parents education, nationality and relationship to the patient was not statistically significant, however Family monthly income and WTP value for the space maintainer were associated (Figure 1).

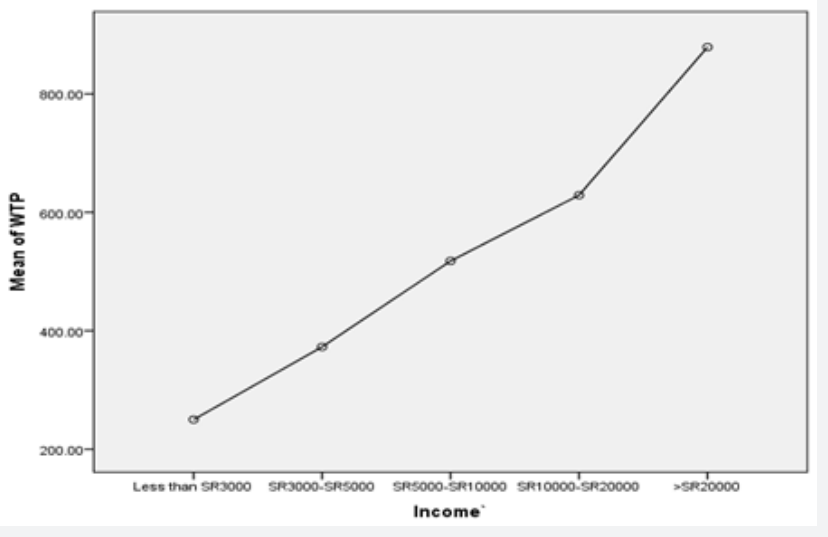

Figure 1: Relation between WTP and monthly income.

\section{Discussion}

Parents preference is rather new in the field of space maintainer research and while WTP is likely to be a preferable method of utility, and as the present study indicates is feasible to conduct despite being time consuming. Bidding is the oldest and most widely used WTP method among the different approaches and has the advantage over other methods of being able to provide a guide on a realistic amount.

Space maintainers are an essential part of interceptive orthodontic treatment. In this study parents were asked about their willingness to pay for a space maintainer, however no effort was made to educate the patient prior to the bidding process. The reason for doing this was to make sure that a baseline score on the willingness to pay was available. In future research we hope to look into the effect of educating the parent on the benefits of space-management on their willingness to pay.

Monthly income has constantly been a factor that influences willingness to pay, some studies have also shown that education of the parent and awareness of the problem can play a role in the WTP for orthodontic treatment. However, the fact that demographic variables such as the parent's education or nationality played no role in the WTP for space maintainers suggests that the importance given to space maintainers is lower than that given to fixed orthodontic treatment. This fact is further supported by the fact that the WTP value in this study approximated to only around half of the market price for space maintainer to preserve the space for the permanent teeth.

\section{Conclusion}

Monthly income was the only factor affects the parent willingness to pay for the space maintainer. There was no statistically significant difference in parent's education, nationality and relationship to the child with the willingness to pay for the space maintainer.

\section{References}

1. O'Brien B, Gafni A (1996) When do the "dollars" make sense? Toward a conceptual framework for contingent valuation studies in health care. Med Decis Making 16(3): 288-299.

2. Cunningham SJ, Hunt NP (2000) Relationship between utility values and willingness to pay in patients undergoing orthognathic treatment. Community Dent Health 17(2): 92-96.

3. Leung KC, McGrath CP (2010) Willingness to pay for implant therapy: a study of patient preference. Clin Oral Implants Res 21(8): 789-793.

4. Tamaki Y, Nomura Y, Teraoka K, Fusao Nishikahara, Mizuho Motegi, et al. (2004) Characteristics and willingness of patients to pay for regular dental check-ups in Japan. J Oral Sci 46(2): 127-133.

5. Smith AS, Cunningham SJ (2004) Which factors influence willingnessto-pay for orthognathic treatment? Eur J Orthod 26(5): 499-506.

6. Cross MJ, March LM, Lapsley HM, Tribe KL, Brnabic AJ, et al. (2000) Determinants of willingness to pay for hip and knee joint replacement surgery for osteoarthritis. Rheumatology (Oxford) 39(11): 1242-1248.

7. Kim SG, Solomon C (2011) Cost-effectiveness of endodontic molar retreatment compared with fixed partial dentures and single-tooth implant alternatives. J Endod 37(3): 321-325.

8. Koberlein J, Klingenberger D (2011) Foreign Dentures and Dental Tourism - Willingness-to-Pay and Factors Influencing the Demand for Foreign Dental Prosthesis in Germany. Gesundheitswesen 73(7): e111-e118.

9. Nowakowska D, Guertin JR, Liu A, Abrahamowicz M, Lelorier J, et al. (2011) Analysis of willingness to pay for implantable cardioverterdefibrillator therapy. Am J Cardiol 107(3): 423-427.

10. Byrne MM, O'Malley KJ, Suarez-Almazor ME (2004) Ethnic differences in health preferences: analysis using willingness-to-pay. J Rheumatol 31(9): 1811-1818.

11. Exley CE, Rousseau NS, Steele J, Finch T, Field J, et al. (2009) Paying for treatments? Influences on negotiating clinical need and decisionmaking for dental implant treatment. BMC Health Serv Res 9: 7.

12. McNamee P, Ternent L, Gbangou A, Newlands D (2010) A game of two halves? Incentive incompatibility, starting point bias and the bidding game contingent valuation method. Health Econ 19(1): 75-87.

13. Onwujekwe O, Nwagbo D (2002) Investigating starting-point bias: a survey of willingness to pay for insecticide-treated nets. Soc Sci Med 55(12): 2121-2130.

14. Fu TT, Lin YM, Huang CL (2011) Willingness to pay for obesity prevention. Econ Hum Biol 9(3): 316-324.

15. Schuh MJ, Droege M (2008) Cognitive services provided by pharmacists: is the public willing to pay for them? Consult Pharm 23(3): 223-230.

16. Birch S, Sohn W, Ismail AI, Lepkowski JM, Belli RF (2004) Willingness to pay for dentin regeneration in a sample of dentate adults. Community Dent Oral Epidemiol 32(3): 210-216.

17. Dixon S, Shackley P (1999) Estimating the benefits of community water fluoridation using the willingness-to-pay technique: results of a pilot study. Community Dent Oral Epidemiol 27(2): 124-129. 

(C) This work is licensed under Creative

DOI: 10.19080/ADOH.2017.05.5555665

\section{Your next submission with Juniper Publishers will reach you the below assets}

- Quality Editorial service

- Swift Peer Review

- Reprints availability

- E-prints Service

- Manuscript Podcast for convenient understanding

- Global attainment for your research

- Manuscript accessibility in different formats

( Pdf, E-pub, Full Text, Audio)

- Unceasing customer service

Track the below URL for one-step submission https://juniperpublishers.com/online-submission.php 